\title{
RESPONSE OF BARLEY PLANTS TO ORGANIC MANURE AND NITROGEN FERTILIZATION UNDER SANDY SOILS CONDITION
}

\author{
A.B. Gaballa *; E. E. Abd El-Moula** and O.A.El - Toumi. *** \\ * Plant Production Department (Agronomy),Efficient Productivity Institute, \\ Zagazig University, Zagazig, Egypt. \\ ** High Job Centre for Complementally,Zawia,Libya. \\ ***Faculty of Veterinary and Agricultural Sciences, $7^{\text {th }}$ of April University, \\ Zawia, Libya.
}

\begin{abstract}
:
Two field experiments were carried out at one of the farm of EL Zawiah Zone, Libya during $2006 / 2007$ and 2007/2008 season to study the response of barley plants $\mathrm{c} v$ California mariot to cheep manure ( 0 , 50,75 and $100 \mathrm{~m}^{3} /$ hectare )and nitrogen fertilizer such as, urea (46\% $\mathrm{N})(100,150$ and $200 \mathrm{~kg} \mathrm{~N} /$ hectare $)$. A split-plot design with three replicates was used in both growing seasons.

The results revealed that, application of organic manure at the rate of $75 \mathrm{~m}^{3}$ hectare gave highest values on vegetative characters(plant height, number of tillers $/ \mathrm{m}^{3}$, number of spikes $/ \mathrm{m}^{3}$,spike length and flag leaf blade area) and total chlorophyll, as well as yield and its components(1000-grain weight, grain yield Ardab/hectare and straw yield).

By increasing the nitrogen fertilization level up to $200 \mathrm{~kg}$ N/hectare gave too the highest values of the characters above mentioned. Regarding the interaction effect, the treatment of $75 \mathrm{~m}^{3}$ cheep manure/hectare and $200 \mathrm{~kg}$ N/hectare, was recorded the highest values of most studied characters in this respect.
\end{abstract}

Key words: Barley, organic manure, nitrogen fertilization.

\section{INTRODUCTION:}

Barley is one of the most of important winter crops in most of the soils at Libyan condition. It is used mainly for feeding animals and for bread making, as well as, it is used for malting in the brewing industry .

More of barley is grown in marginal lands either macro or micro elements. And thus, organic manuring and nitrogen fertilization are considered among the most important cultural practices for increasing barley productivity. 
Many investigators were studied the response of barley plants to organic manure application, they reported and illustrated that organic manure improves the proprieties of the soil and increased the growth characters, grain and as well as, straw yields 1000 - grain weight. In addition, increased the chlorophyll content in barley leaves ( Sharma et al., 2001; El - Toukhy and Abd-Alla, 2002, Salib Madlain et al., 2002; Bereez et al., 2005 and Gaballah and Mowafy, 2007).

Nitrogen fertilization increased plant growth parameters, yield and its components, chlorophyll content of leaves of barley plants (Abd-Alla, Maha, 2004; El-Moselhy and Zahran, 2003 and Kotb and Gaballa, 2007). This investigation aimed to study the response of barley plants to fertilization with organic manure and nitrogen fertilization under sandy soils condition.

\section{MATERIALS AND METHODS}

Two field experiments were carried out at one of the farm of EL Zawiah Zone, Libya during 20062007 and 2007 / 2008 season to study the response of barley plants cv California mariot to organic manure, i.e.cheep manure $(0,50,75$ and $100 \mathrm{~m}^{3} /$ hectare) and nitrogen fertilizer such as, urea $(46 \% \mathrm{~N})(100,150$ and $200 \mathrm{~kg} \mathrm{~N} /$ hectare).

A split-plot design with three replicates was used in both growing seasons. The organic manure treatments were assigned to the main plots and nitrogen fertilizer levels were distributed in the sub- plots. Plot area was $9 \mathrm{~m}^{2}(3 \mathrm{x}$ 3 ) including 15 rows $20 \mathrm{~cm}$ apart in $3 \mathrm{~m}$ long. Barley seeds were sown by hand drilling on $18^{\text {th }}$ and $19^{\text {th }}$ of November in the first and second seasons, respectively. The soil of the experimental site is sandy in texture. Chemical analysis of the soil are shown in Table 1 and cheep manure are shown in Table 2.

The sub-plots included nitrogen fertilizer levels (100, 150 and $200 \mathrm{Kg}$ / hectare), which applied at three equal doses. The first dose was added during seedbed preparation and the second and the third after three weeks between its ,respectively.

Tables 1. The chemical analysis of the experiment soil.

\begin{tabular}{ll}
\hline Characters & Values \\
\hline Available potassium & $115 \mathrm{ppm}$ \\
Available nitrogen & $88 \mathrm{ppm}$ \\
pH & 7.6 \\
Organic manure & $0.8 \%$ \\
Cation exchangeable Capacity ( C.E.C.) & $19.0(\mathrm{meg} . / 100 \mathrm{~g} . \mathrm{soil})$ \\
Soil texture & Sandy loam \\
\hline
\end{tabular}


Table 2. The chemical analysis of used cheep manure in the experiment soil.

\begin{tabular}{ll}
\hline Chemical contents and characters & Values \\
\hline pH & 6.8 \\
Electric Conductivity (EC) & $3.6(\mathrm{~mm} / \mathrm{cm})$ \\
Total organic carbon & $26.8 \%$ \\
C/N ratio & $1: 33.5$ \\
Total nitrogen & $0.9 \%$ \\
Total potassium & $0.3 \%$ \\
Aching & $6 \%$ \\
Moisture & $55 \%$ \\
\hline
\end{tabular}

The other agronomic practices were adopted as recommended in ElZawiah zone soils condition. Spray irrigation system was used .

After 90 days from sowing, a ten competitive plants were randomly taken the second inner rows of each plot to determine the vegetative growth characters as follows:

1- Plant height $(\mathrm{cm})$ was determined from the soil surface to the top of the main spike excluding awns.

2- Flag leaf blade area $\left(\mathrm{cm}^{2}\right)$,(long $\mathrm{x}$ width $\mathrm{x}$ 0.72).

3- Total chlorophyll (mg/g ): (chlorophyll a + chlorophyll b ).

Chlorophyll and $\mathrm{a} b$ were determined according to the method of Fadeel (1962) by using spectrophotometrically at $662 \mathrm{~nm}$ and $644 \mathrm{~nm}$ to determine chlorophyll $a$ and $b$, respectively.

At harvest time, an area of two $\mathrm{m}^{2}$ from each plot was harvested to determine:

1- Number of tillers $/ \mathrm{m}^{2}$.

2- Number of spikes $/ \mathrm{m}^{2}$.

3- 1000-grain weight (g)

4- Grain yield ardab / hectare.$($ Ardab $=120 \mathrm{~kg})$.

5-Straw yield (ton / hectare ). ( Ton $=1000 \mathrm{~kg}$; Hectare $=10000 \mathrm{~m}^{2}$ ).

The results were subjected to standard analysis of variance according to the procedure described by Snedecor and Cochran (1980). for comparison between means, Duncan,s multiple test was used (Duncan, 1955). 


\section{RESULTS AND DISCUSSION}

Vegetative growth and chlorophyll content :

a. Effect of organic manure :

Data illustrated in Table (3) indicate clearly that plant height, both number of tillers and spikes per $\mathrm{m}^{2}$, spike length and flag leaf blade area as well as total chlorophyll were significantly increased with increasing rate of organic manure (cheep manure) up to $75 \mathrm{~m}^{3} /$ hectare and then decreased.

The increment in barely vegetative growth might be attributed to the role of organic manure for releasing the macro and micro elements to barely plants in enhancing the growth and dry matter accumulation (Yakout et al., 1998). These results are in agreement with those reported by Sharma et al, 2002; El-Toukhy and Abd -Alla, 2002; Salib, Madlain et al., 2002; Bereez et al., 2005 and Gaballah and Mowafy, 2007 ).

\section{b- Effect of nitrogen fertilization :}

Data in Table (3) revealed that barely vegetative growth characters and chlorophyll content above mentioned were significantly increased by increasing $\mathrm{N}$ level form 100 to $200 \mathrm{~kg} /$ hectare As the role of nitrogen nutrient in plants, Edmond et al. (1981) concluded that nitrogen is an indispensable elementary constituent of numerous organic compounds of general importance (amino acids, protein, nucleic acids and it increased in formation of protoplasm and new cells as well as encourage for cell elongation. These results are confirmed with the results obtained by Sarhan et al. (2002); Abd-Alla Maha (2004); El - Moselhy and Zahran(2003); El Bawab et al.(2003) and Kotb and Gadalla (2007).

\section{Yield and it components :}

\section{a- Effect of organic manure :}

Data in Table (4) illustrated that 1000- grain weight, grain yield / hectare and straw yield / hectare were significantly increased by increasing organic manure rate from 50 to $75 \mathrm{~m}^{3}$ /hectare and then decreased. The increments in barely yield with $75 \mathrm{~m}^{3}$ /hectare may be attributed to the good vegetative plant growth (Table 3) and to the improving effect of micro and macro - elements contained in organic manure which important for the activity of the bio-operations and the accumulation of metabolism in reproductive organs and this reflects on the spikes and grains and total yield. These results are in confirming with those reported by Bereez et al. (2005) and Gaballh and Mowafy (2007). 
GABALLA ET AL 


\section{b- Effect of nitrogen fertilization :}

Data in Table (4) showed also that 1000 - grain weight, grain yield (Ardab /hectare)and straw yield (ton/hectare) were significantly increased by increasing $\mathrm{N}$-level from 100 to $200 \mathrm{~kg} / \mathrm{hectare}$, in both growing seasons.

The favorable effect of $\mathrm{N}$ - application (200 kg / hectare) are recommended for barely to stimulate plant growth (Table 3) and yield and it,s components (Table 4). These results are in agreement with those reported by Noworolink and Pecio, 1989; El - Hindi et al, 1998; El - Kholy et al., 1998; Abd - Alla, Maha, 2004; El - Moselhy and Zahran, 2003; El Bawab et al., 2003 and Kotb and Gaballa, 2007.

Regarding to the interaction between $75 \mathrm{~m}^{3} /$ hectare (cheep manure) and $200 \mathrm{~kg} /$ hectare ( $\mathrm{N}$-fertilization, urea ) increased the most of characters studied in both seasons of experiment under El-Zawiah zone soil condition in Libya (Tables 5 and 6).

Conclusively, it can be concluded that the best treatment for high barely plant growth, total chlorophyll content of leaves and yield and its components were $75 \mathrm{~m}^{3} /$ hectare (cheep manure), $200 \mathrm{~kg} /$ hectare $(\mathrm{N}-$ fertilization), as well as, the interaction between $75 \mathrm{~m}^{3} /$ hectare (cheep manure) and $200 \mathrm{~kg} /$ hectare ( $\mathrm{N}$-fertilization,urea) in both seasons of experiment under El-Zawiah zone soil condition in Libya (Tables 5 and 6 ).

\section{REFERENCES}

Abd Alla, Maha, M. (2004). Influence of nitrogen level and its application time on yield and quality of some new hull -less barley. Journal of Agriculture Science, Mansoura University, 29 (5) :2201-2216.

Bereez, K. ; T. Kismanyoky and K. Dbreczeni (2005). Effect of organic matter recycling in long-term fertilization trials and model pot experiments. Communications in Soil Science and Plant Analysis, 36 (113): $191-202$.

Duncan, D. B. (1955). Multiple range and multiple F- test. Biometrics, 11: $1-24$.

El-Bawab, A. M.O. ; M. A. EL - Moselkey and M. A. Megahed (2003). Water and fertilizer requirements for barley in sandy soils. Egyptian Journal of Applied Science, 18 (7) : 125 - 133. 
GABALLA ET AL 
El-Hindi, M. H. ; A. T. EL-Kassby ; A. E. Sharief and K. A. Amer (1998). Yield of barley as afferent sources and levels of nitrogen fertilization under the environmental conditions of newly reclaimed soils at northern delta of Egypt. Proceeding 8th Conference of Agronomy, Suez Canal University, Ismailia, Egypt, 28 - 29 Nov., $153-158$.

El-Kholy, M. A. and A. M. O. EL-Bawab ( 1998 ). Response of some barley cultivars to nitrogen fertilization and stimophol as a foliar application. Proceeding 8th Conference of Agronomy, Suez Canal University, Ismailia , Egypt , 28 -29 Nov., 145-152 .

EI - Moselhy, M. A. and F. A. Zahran (2003). Effect of bio and mineral nitrogen fertilization on barley crop grown on a sandy soil. Egyptian Journal. of Agriculture Research, 81 ( 3 ) : 921 -935 .

El-Toukhy, S. A. and S. O. M. Abd-Alla (2002). Forage yield and nutritive value of some pasture species interopped with Acacia Saligna under saline conditions. Annals of Agriculture Science, Cairo, 47 (1): 237 - 254.

Fadeel, A. A. (1962). Location and properties of chloroplast and pigment determination in roots. Plant Physiology, 15: 130-147.

Gaballa , A. B. and S. A. El-Mowafy (2007). Response of some barley cultivars to organic manuring and foliar application of the micronutrients mixture fertilan 10 under new reclaimed sandy soil conditions. $J$. Product. \& Dev., 12 ( 1$): 1-12$.

Kotb, A. M. and A. B. Gaballah (2007). Influence of glycinebetaine and nitrogen levels on growth and yield of barley (Hordeum vulgare L.) under drought conditions. J. Product. \& Dev., 12 (1): 45 - 60.

Noworolink, K. and A. Pecio (1989). Effect of nitrogen fertilization on the productivity of new cultivars of winter barley. PomietnkPulawasski (Poland). ( 1992 ), No.95;60-82, Distributed .

Salib , Madlain, M. ; R. N. Zaki and M. A. Negm (2002). A comparative study on the significance of applied farmyard manure and other affording materials for barley grain on saline soil. Zagazig Journal Agricuture Research, 29 ( 4 ): 1185 - 1198 .

Sarhan,A. A. I.; M .A. Megahed and F. A. F. Zahan (2002). Response of barley to $\mathrm{N}$ and $\mathrm{K}$ Fertilization under sandy soil conditions. $J$. Product. \& Dev., 7 (1): 19-36 .

Sharma, R. R. I;V.K.Suri and N. Datt (2001). Integrated nutrient management in summer barley (Hordeum vulgare) in a cold desert of Himachal Pradesh .Indian Journal of Agriculture Science,71 (12): $752-755$. 
Snedecor, G. W. and W. G. Cochran (1980). Statistical Methods. Iowa State University, $7^{\text {th }}$ ed. Press. Ames Iowa , U.S.A.

Yakout,G. M. I.;M. H. Greish and R. A. Ata-Alla (1998). Response of wheat crop to seeding rates, nitrogen fertilizer and organic manure under new reclaimed soil Conditions Proceeding 8th Conference of Agronomy, Suez Canal University, Ismailia, Egypt , 28-29 Nov.

\section{استجابة نباتات الشعير للتسميد العضوي والنيتروجين تحت ظروف التروفي الاراضى الرملية}

$$
\begin{aligned}
& \text { السيد بيومي جاب الله*، الطاهر الهادي عبد المولى ، عمر احمد التومى التهى }
\end{aligned}
$$

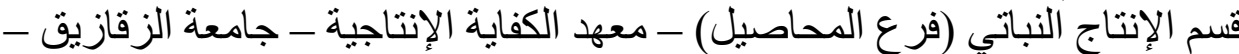

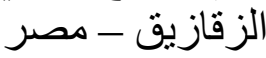

$$
\begin{aligned}
& \text { *** المعهد العالي للمهن الثاملةــ بالز اوية ـ ليبيا } \\
& \text { **** كلية البيطرة و العلوم الزر اعية ـ جامعة السابع من أبريل ــ الز اوية ـ ليبيا }
\end{aligned}
$$

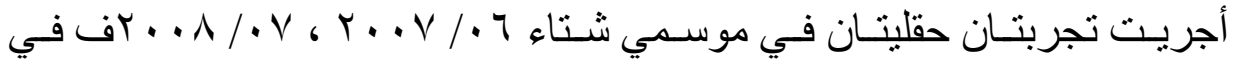

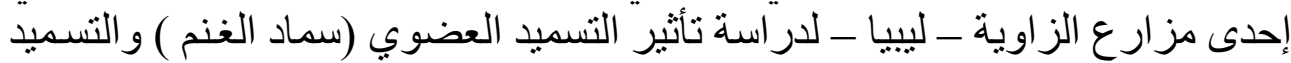

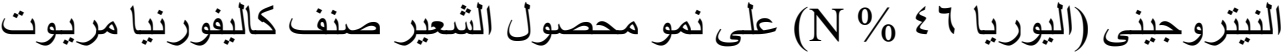

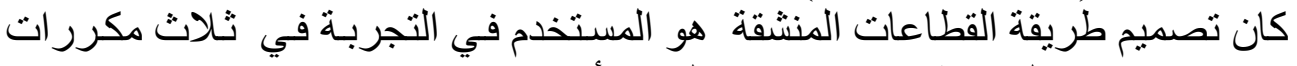

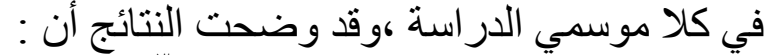

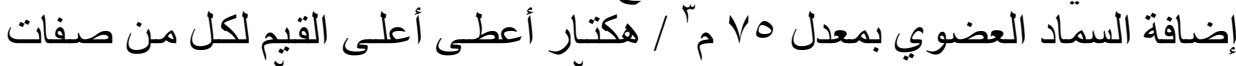

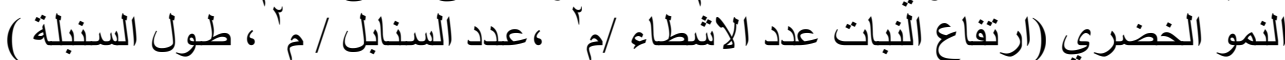

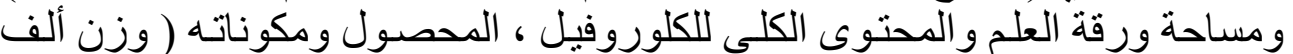

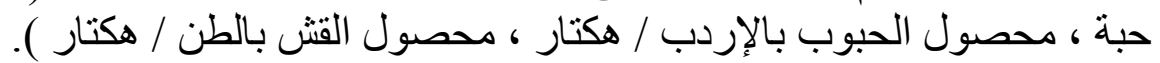
بزيـادة إضـافة التسميد النيتروجينى حتى أعلى معدل أعطى أعلى القيم أيضـا

$$
\text { للصفات المذكورة سابقا. }
$$

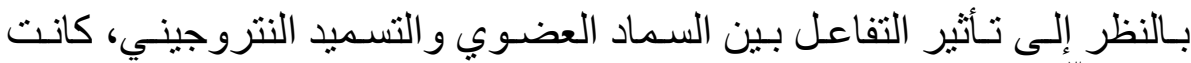

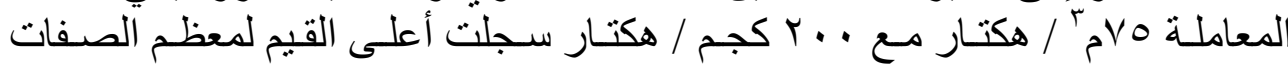
المدروسة. وتحت ظروف الار اضى الليبية المشابهة لأر اضى التجربة يوصى باستخدام هذه المعدلات 